\title{
Recent patent applications in animal models
}

\begin{tabular}{|c|c|c|c|c|c|}
\hline Patent number & Description & Assignee & Inventor & $\begin{array}{l}\text { Priority } \\
\text { application } \\
\text { date }\end{array}$ & $\begin{array}{c}\text { Publication } \\
\text { date }\end{array}$ \\
\hline WO 2013039271 & $\begin{array}{l}\text { An animal model, e.g., Primates, Rodentia other than mice, } \\
\text { Lagomorpha, Insectivore, Carnivora, Perissodactyla or Artiodactyla, of } \\
\text { frontal lobe dysfunction with a cobalt wire implanted to its frontal lobe; } \\
\text { useful for screening a substance for alleviating frontal lobe dysfunction. }\end{array}$ & $\begin{array}{l}\text { Korea Advanced } \\
\text { Institute of } \\
\text { Science and } \\
\text { Technology } \\
\text { (Daejeon, South } \\
\text { Korea) }\end{array}$ & Kim DS, Kim JJ & 9/16/2011 & $3 / 21 / 2013$ \\
\hline JP 2013048606 & $\begin{array}{l}\text { A method of preparing a hepatitis B onset human hepatocytes chimeric } \\
\text { animal model, by administering anti-asialo GM } 1 \text { antibody, clodronate } \\
\text { and human blood mononuclear cells to the human hepatocytes chimeric } \\
\text { animal model infected with the hepatitis B virus. }\end{array}$ & $\begin{array}{l}\text { Hiroshima } \\
\text { University } \\
\text { (Hiroshima, } \\
\text { Japan) }\end{array}$ & Chayama K & $8 / 31 / 2011$ & $3 / 14 / 2013$ \\
\hline US 20130061339 & $\begin{array}{l}\text { A method for diagnosing impulse control disorders, autism and } \\
\text { Parkinson's disease, comprising measuring a reductive capacity in a } \\
\text { sample of bodily fluid from a patient. The method also claims an animal } \\
\text { model for trichotillomania. }\end{array}$ & $\begin{array}{l}\text { Purdue } \\
\text { Research } \\
\text { Foundation } \\
\text { (W. Lafayette, } \\
\text { IN, USA) }\end{array}$ & $\begin{array}{l}\text { Garner J, } \\
\text { Lossie AC, } \\
\text { Vieira GDLT }\end{array}$ & $8 / 3 / 2011$ & $3 / 7 / 2013$ \\
\hline WO 2013029472 & $\begin{array}{l}\text { A composition useful for extracting circulating unrelated nucleated rare } \\
\text { cells from the blood of a disease animal model, where the unrelated } \\
\text { nucleated rare cells are circulating solid tumor cells of epithelial origin, } \\
\text { circulating vascular endothelial cells or tumor stem cells. }\end{array}$ & $\mathrm{LuH}$ & $\mathrm{LuH}$ & $8 / 30 / 2011$ & $3 / 7 / 2013$ \\
\hline JP 2013042693 & $\begin{array}{l}\text { A method for preparing nephrotic syndrome animal model, involving } \\
\text { causing nephrin abnormality between epithelial cells of kidney glom- } \\
\text { erulus by administering antibody against full-length nephrin cDNA to a } \\
\text { non-human animal and developing symptoms of nephrotic syndrome in } \\
\text { the animal model. }\end{array}$ & $\begin{array}{l}\text { Kitasato Gakuen } \\
\text { (Tokyo) }\end{array}$ & $\begin{array}{l}\text { Kamata K, } \\
\text { Okamoto T }\end{array}$ & $8 / 24 / 2011$ & $3 / 4 / 2013$ \\
\hline WO 2013028871 & $\begin{array}{l}\text { A cell of an inducible transgenic mouse that is a model of lung cancer; } \\
\text { useful for screening a therapeutic agent for treating lung cancer and } \\
\text { lung remodeling disease, e.g., emphysema or chronic obstructive } \\
\text { pulmonary disease. }\end{array}$ & $\begin{array}{l}\text { University of } \\
\text { South Florida } \\
\text { (Tampa, FL, } \\
\text { USA) }\end{array}$ & Dave VG & $8 / 23 / 2011$ & $2 / 28 / 2013$ \\
\hline WO 2013026059 & $\begin{array}{l}\text { Inhibiting tumor growth in a subject, involving producing an orthotopic } \\
\text { nonhuman mammal model of pancreatic cancer and administering to a } \\
\text { subject an agent that inhibits granulocyte macrophage colony stimulat- } \\
\text { ing factor and/or an agent that inhibits myeloid-derived suppressor cell } \\
\text { activity under conditions effective to inhibit tumor growth in the subject. }\end{array}$ & $\begin{array}{l}\text { New York } \\
\text { University } \\
\text { (New York) }\end{array}$ & $\begin{array}{l}\text { Bar-Sagi D, } \\
\text { Lee KE, } \\
\text { Pylayeva-Gupta Y }\end{array}$ & 8/18/2011 & $2 / 21 / 2013$ \\
\hline JP 2013034401 & $\begin{array}{l}\text { A glial cell-specific expression vector, and a nonhuman mammal } \\
\text { obtained by introducing the vector into its cerebellum and expressing } \\
\text { the target gene; useful as animal model for cerebellum disruptive } \\
\text { disease. }\end{array}$ & $\begin{array}{l}\text { Gunma } \\
\text { University } \\
\text { (Maebashi, } \\
\text { Japan) }\end{array}$ & Hirai $\mathrm{H}$ & $8 / 4 / 2011$ & $2 / 21 / 2013$ \\
\hline WO 2013017551 & $\begin{array}{l}\text { A method of inducing an increase in intraocular pressure in an animal } \\
\text { used as model of glaucoma, by performing ocular administration of a } \\
\text { solution comprising benzalkonium chloride. }\end{array}$ & $\begin{array}{l}\text { Institut National } \\
\text { de la Santé et } \\
\text { de la Recherche } \\
\text { Médicale (Paris) }\end{array}$ & $\begin{array}{l}\text { Baudouin C, } \\
\text { Denoyer A, } \\
\text { Godefroy D, } \\
\text { Rostene W }\end{array}$ & $7 / 29 / 2011$ & 2/7/2013 \\
\hline WO 2013017545 & $\begin{array}{l}\text { Transgenic mouse or mouse cell comprising functional human leukocyte } \\
\text { antigen (HLA)-A2 and HLA-DP4 transgenes; useful for developing moni- } \\
\text { toring biomarkers, evaluating innovative vaccines and immunotherapies } \\
\text { and decrypting the correlation between some DP4-restricted response } \\
\text { and disease prevention or pathogenesis. }\end{array}$ & $\begin{array}{l}\text { Institut National } \\
\text { de la Santé et } \\
\text { de la Recherche } \\
\text { Médicale (Paris) }\end{array}$ & Lone YC & $7 / 29 / 2011$ & $2 / 7 / 2013$ \\
\hline
\end{tabular}

Source: Thomson Scientific Search Service. The status of each application is slightly different from country to country. For further details, contact Thomson Reuters (Search Service), 1925 Ballenger Avenue, Suite 400, Alexandria, VA 22314, USA. Tel: 1 (800) 337-9368 (http://thomsonreuters.com/). 